\title{
DISCOGRAFÍA DE VIOLETA PARRA
}

\author{
Miguel Naranjo Ríos
}

RESUMEN: Este documento presenta el catálogo discográfico de Violeta Parra, junto a carátulas que acompañaron su producción. La discografía - cuyo conjunto es integrado por canciones de su propia autoría y otras recopiladas en un valioso trabajo de investigación- está conformada por: (1) grabaciones integrando el dúo Hermanas Parra; (2) sus grabaciones como solista en vida; (3) grabaciones póstumas; y (4) colaboraciones con otros artistas.

Palabras clave: Violeta Parra, discografía, familia Parra, folclor chileno.

\section{VIOLETA PARRA'S RECORD CATALOGUE}

ABSTRACT: This document presents a catalogue of Violeta Parra's records and the accompanying sleeves. This catalogue includes songs written by Violeta Parra herself and others collected by her in the course of her important research, and comprises: (1) recordings made with her sister Hilda as part of the Hermanas Parra duo; (2) recordings as a soloist released in her lifetime; (3) recordings released posthumously; and (4) collaborations with other artists.

Keywords: Violeta Parra, record catalogue, Parra family, Chilean folklore.

\footnotetext{
Q uienquiera que hable la lengua de Violeta Parra puede entender y disfrutar las letras de sus canciones - recopiladas, musicalizadas o creadas por ella_-, y ése es uno de sus mayores méritos como poeta y como cantora: su aprehensibilidad.
}

Miguel Naranjo Ríos. Poeta. Autor de Verso (2006) y Libro (2016). Email: miguel. naranjo.rios@gmail.com. 
Su voz y su guitarra han llegado a la mayoría de nosotros a través de grabaciones para la industria musical que comenzaron en discos de acetato y que tuvieron como soporte mayoritario el disco de vinilo, aunque también quedaron grabaciones inéditas suyas.

Con el advenimiento del vinilo, los sellos se abocaron más al diseño de sus carátulas, a tal punto que a veces una obra musical está ligada a la gráfica de su envase. Y Violeta Parra en algunas ocasiones tuvo injerencia directa en la realización de sus propias carátulas, proponiendo a algún artista para diseñar la portada o bien cooperando con alguna obra visual suya.

Entonces ver y tocar sus discos es adentrarse en parte de su historia. Así, esta discografía se ha restringido sólo a soportes de acetato y vinilo, aunque casetes y cedés se han encargado de reeditarla y de dar a conocer de a poco temas inéditos.

La presente discografía está divida en cuatro partes. La primera trata acerca de sus grabaciones cuando integró el dúo Hermanas Parra con su hermana Hilda y después con su hija Isabel. En la segunda se revisan sus grabaciones como solista en vida. En la tercera se mencionan grabaciones póstumas. Y la cuarta sección trata acerca de sus colaboraciones con otros artistas.

En el listado de canciones, éstas aparecen tal cual se citan en el respectivo disco, pero entre corchetes se agrega si ha tenido otro título en una grabación distinta.

Los temas cuya autoría es de Violeta Parra aparecen con asterisco. Los demás son recopilaciones, salvo si se indica otra cosa.

\section{HERMANAS PARRA}

Violeta y su hermana Hilda conformaron el dúo Hermanas Parra. Sus grabaciones son difíciles de rastrear, pero habrían comenzado en 1952 con discos de acetato grabados para RCA Victor. Hilda afirma que la primera canción que grabaron juntas se llama "Mujer ingrata", y ambas declaran haberse separado en $1953 .^{1}$

${ }^{1}$ Patricia Štambuk y Patricia Bravo, Violeta Parra: el canto de todos (Santiago: Pehuén, 2011), 61 y 64. Marisol García ed., Violeta Parra en sus palabras. Entrevistas (1954-1967) (Santiago: CIP UDP / Catalonia, 2017), 15. 
Canciones que grabaron que se han podido identificar son "Se fue el año viejo"*, "En el norte"*, "Ven", "La misa del gallo"*, "Qué rica cena"*, "Judas"*, "El buen consejo"* y "Por la mañanita"*.

La siguiente imagen corresponde a uno de esos acetatos:

\subsection{Hermanas Parra: "El buen consejo" $y$ "Por la mañanita" $(1954)^{2}$} RCA Victor 90-1426, disco de acetato 10" 78 RPM, Chile.

Contiene lado A: "El buen consejo"*. Lado B: "Por la mañanita"*.

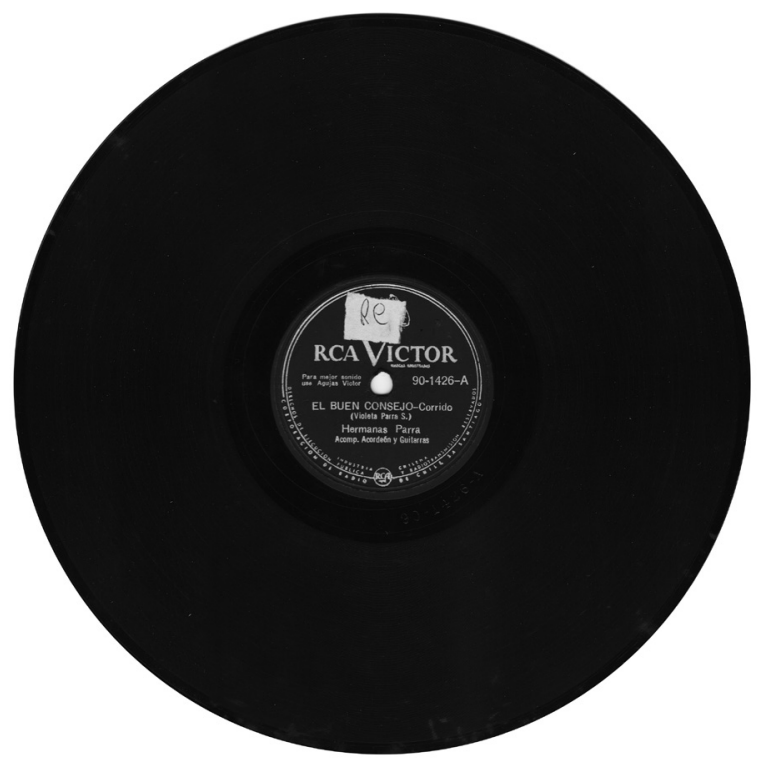

En 1954 también se publica otro acetato de Hermanas Parra pero para Odeon (89-952), en el cual se incluyen "La jardinera"* y "Es imposible", pero quien acompaña a Violeta en el dúo ahora es su hija Isabel.

Terminados estos dúos, el sello Odeon ha editado - en discos de vinilo- compilaciones de cuecas de diversos artistas, en los que se han incluido algunas por Hermanas Parra.

${ }^{2}$ Agradezco a Eugenio Bastías por haberme facilitado este acetato de Hermanas Parra, que pertenece a su discoteca. El año de publicación del disco lo averiguó por nosotros el mismo dueño del disco en la "Sección novedades" de la revista $L a$ Voz de RCA Victor (septiembre de 1954), 20. 
Las cuecas que han aparecido en estas compilaciones interpretadas por Violeta e Isabel son: "La viudita", "Ojos negros y pardos" y "La monona".

Las cuecas que han aparecido en estas compilaciones interpretadas por Violeta e Hilda son: "La cueca del payaso", "Ciento cincuenta pesos", "La cueca del sastre", "El panadero", "A mi casa llega un gato" y "El cuartel es una fonda", cueca esta última en la que se deja entrever una peculiar visión acerca de los militares, que seguramente comparten las intérpretes.

La siguiente imagen corresponde a uno de esos discos:

\subsection{Hermanas Parra / Los campesinos (1957)} Odeon DSOD-E 50097, EP 7”, 45 RPM, Chile.

Contiene de Hermanas Parra: "La cueca del payaso", "Ciento cincuenta pesos", "La cueca del sastre".

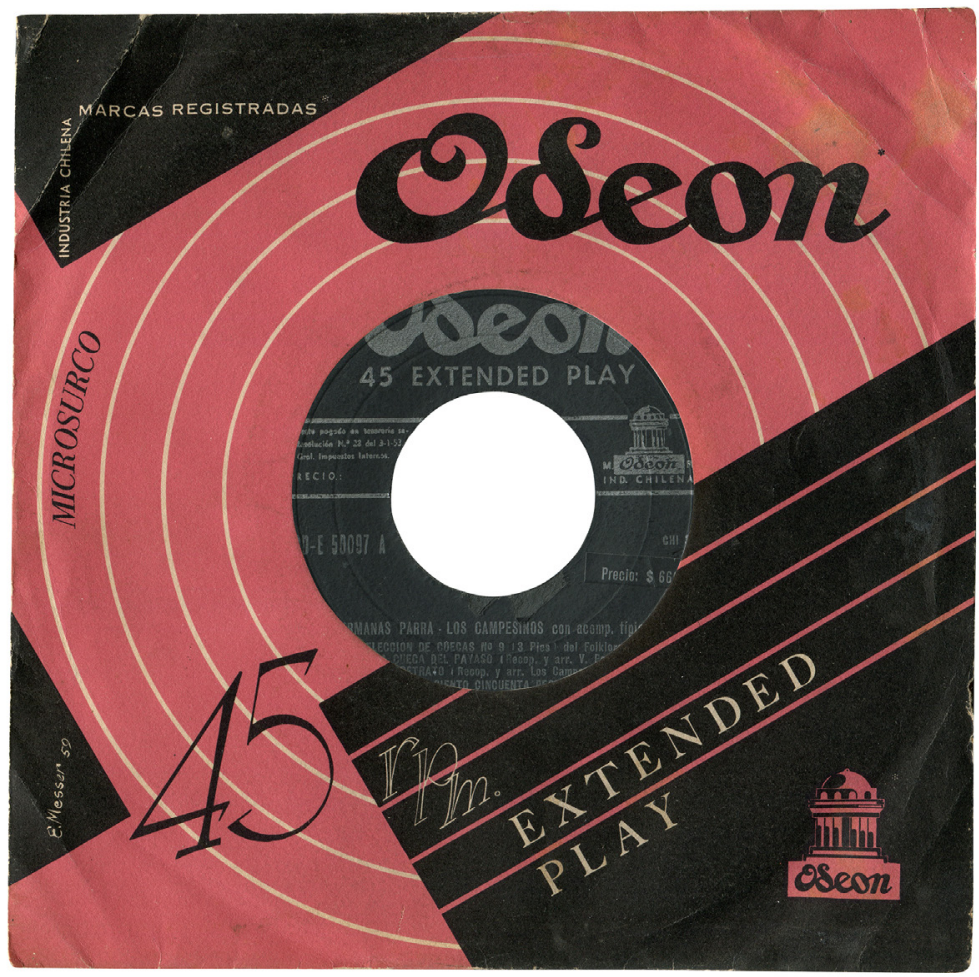




\section{DISCOGRAFÍA EN VIDA}

\subsection{Violeta Parra con acompañamiento típico (1955)}

Odeon DSOD/E-50040, EP 7" 45 RPM, Chile.

Contiene lado A: "Qué pena siente el alma", "Verso "Por el fin del mundo" ["Verso por el Apocalipsis"]. Lado B: "Casamiento de negros" (del folclor chileno / Violeta Parra), "Verso 'por padecimiento".

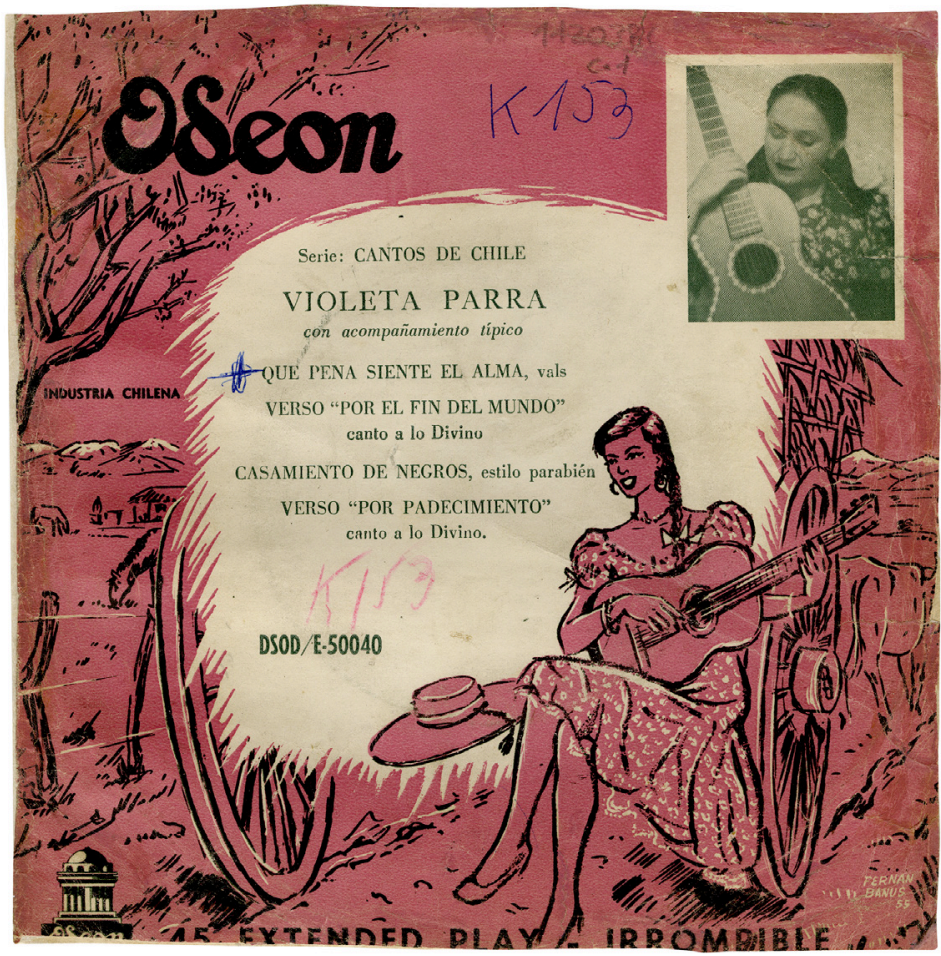

Éste es el primer vinilo publicado por Violeta Parra. ${ }^{3}$ La portada es de Fernán Banus. El tema inicial es "Qué pena siente el alma", una canción que grabará varias veces. También se incluye "Casamiento de negros", grabada también varias veces por Violeta.

${ }^{3}$ La reproducción de esta imagen es gentileza del Archivo de Música de la Biblioteca Nacional de Chile. 


\subsection{Violeta Parra con su guitarra (1955)}

Odeon DSOD/E-50059, EP 7" 45 RPM, Chile.

Contiene lado A: "El palomo", "Verso por ponderación". Lado B: "La Juana Rosa"*, "Lágrimas de Carabaña" ["Los paires saben sentir"].

2.3. Violeta Parra: "La jardinera"* y "La muchacha" ["Meriana"] (1955)

Leningradsky Zavod 5289-50, disco de acetato 10" 78 RPM, Unión Soviética.
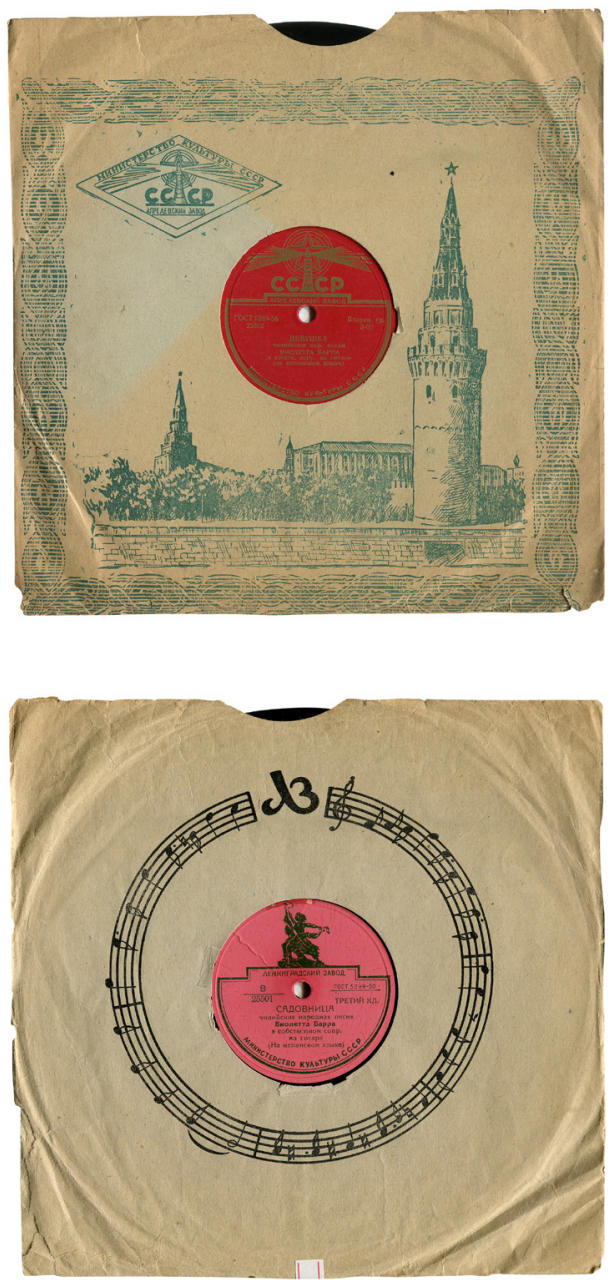
En las imágenes se muestran dos ediciones. ${ }^{4}$ Se incluye "La jardinera", una de sus composiciones tempranas más conocidas y que grabara varias veces. "Meriana" es precursora en la grabación de música pascuense.

\subsection{Chants et danses du Chili I (1956)}

Le Chant du Monde LDY-4060, EP 7" 331⁄3 RPM, Francia.

Contiene lado A: "Aquí se acaba esta cueca", "Qué pena siente el alma", "La jardinera"*, "Casamiento de negros" (del folclor chileno / Violeta Parra). Lado B: "Cantos a lo divino", "Miren cómo corre el agua", "La refalosa" ["Arriba de aquel árbol"], "Paimiti".

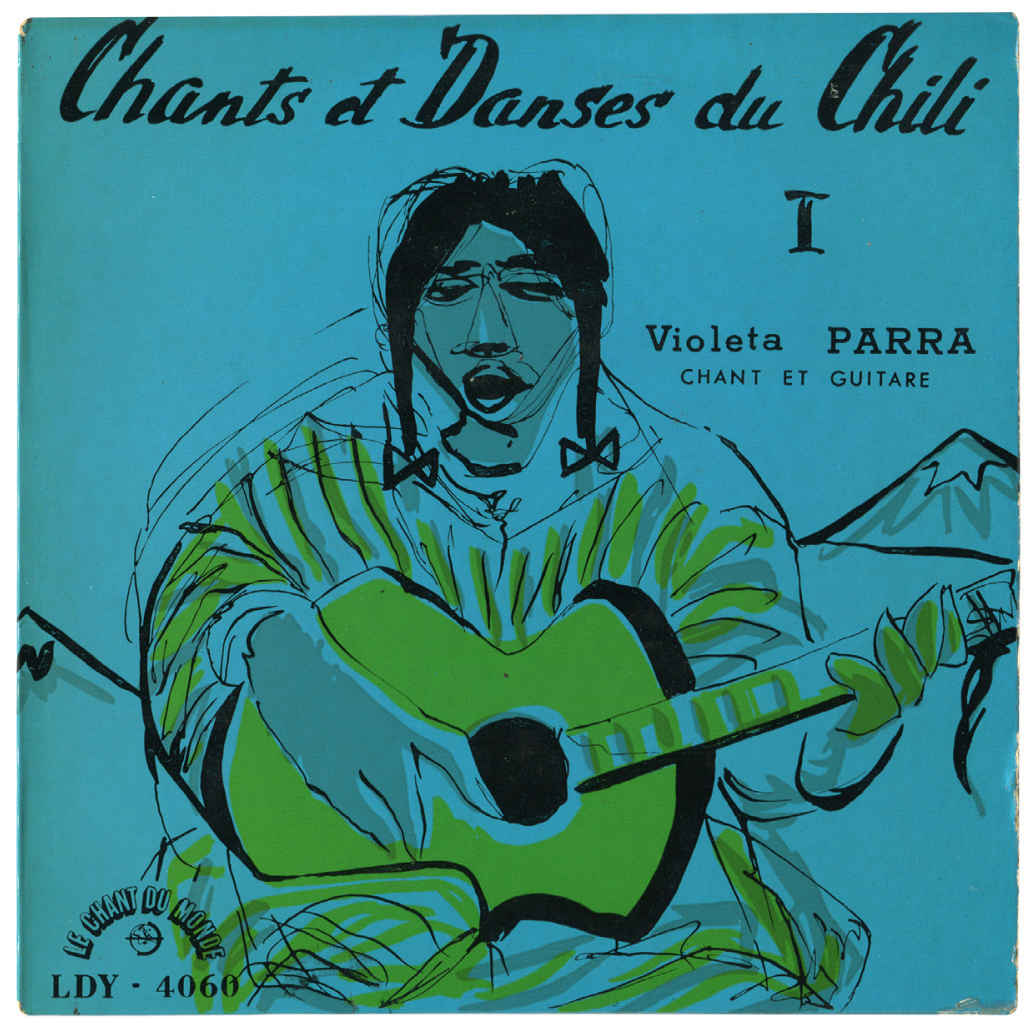

${ }^{4}$ Agradezco a Anna Kosolapova por haberme obsequiado uno de estos discos rusos de Violeta Parra. 


\section{Chants et danses du Chili II (1956)}

Le Chant du Monde LDY-4071, EP 7" 331⁄3 RPM, Francia.

Contiene lado A: "Parabienes de novios" ["Viva la luz de Don Creador"], "Ausencia", "El palomo", "Dicen que el ají maduro". Lado B: "Viva Dios" ["Viva Dios, viva La Virgen”], "A Lulu", "Versos por el Apocalipsis", "Meriana".

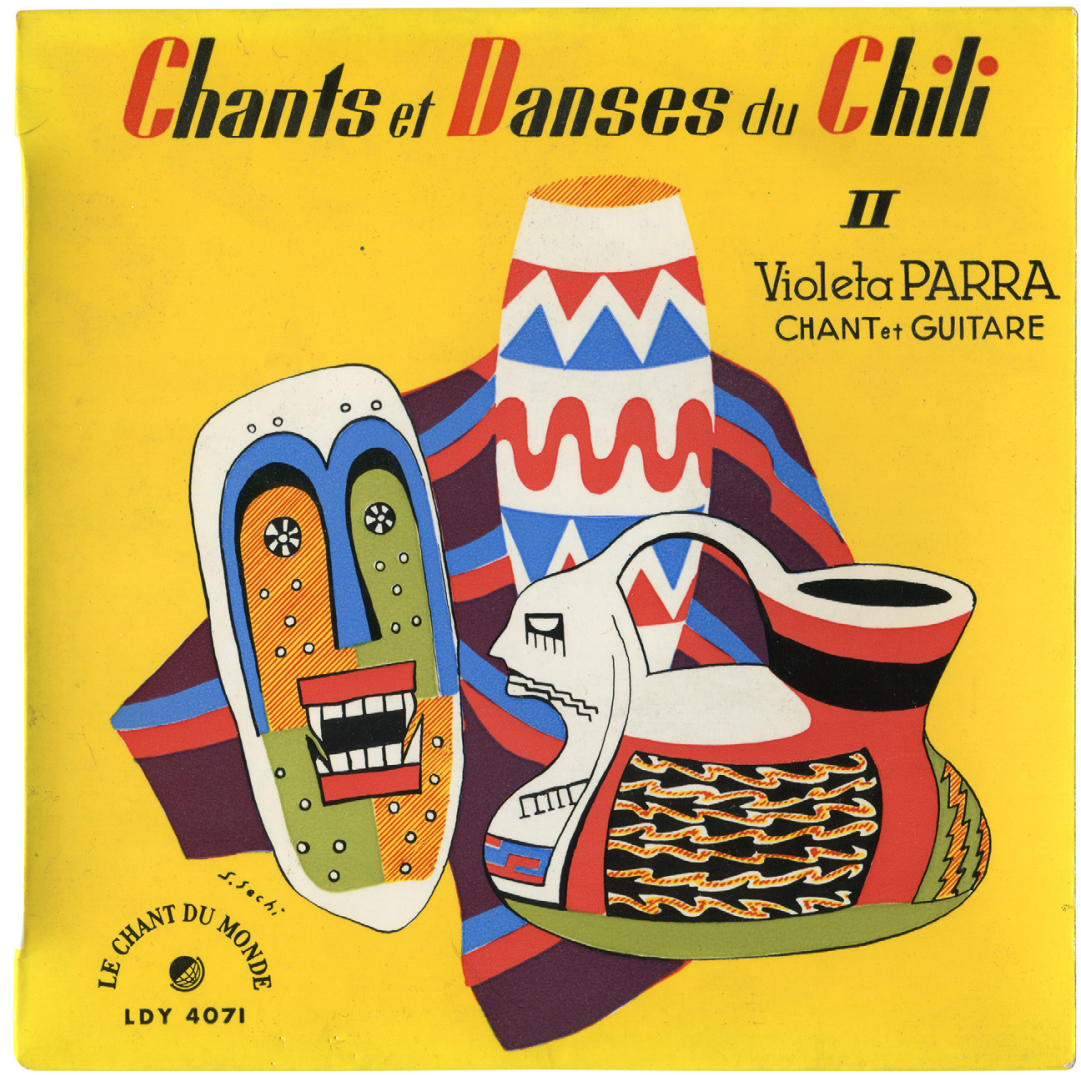

En Francia graba para el sello Le Chant du Monde, casa grabadora dedicada a la música tradicional de diferentes partes del mundo. De estas grabaciones surgen dos discos, ambos grabados en un solo día, el 26 de marzo de 1956. Otras canciones grabadas durante esa misma sesión se publicarán póstumamente (ver ítem 3.3). 


\subsection{Violeta Parra, canto y guitarra (1957)}

Odeon LCD-36019, LP 12" 331주 RPM, Chile.

Contiene lado A: "La inhumana", "Es aquí o no es aquí", "Son tus ojos", "Parabienes al revés"*, "Tres cuecas punteadas", "Verso por saludo", "Ausencia", "Las naranjas", "El sacristán". Lado B: "Verso por la sagrada escritura", "Viva la luz de don Creador", "El bergantín", "Verso por la niña muerta"*, "Tres polcas antiguas", "Verso por despedida a Gabriela Mistral"*, "No habiendo como la maire", "La paloma ingrata".

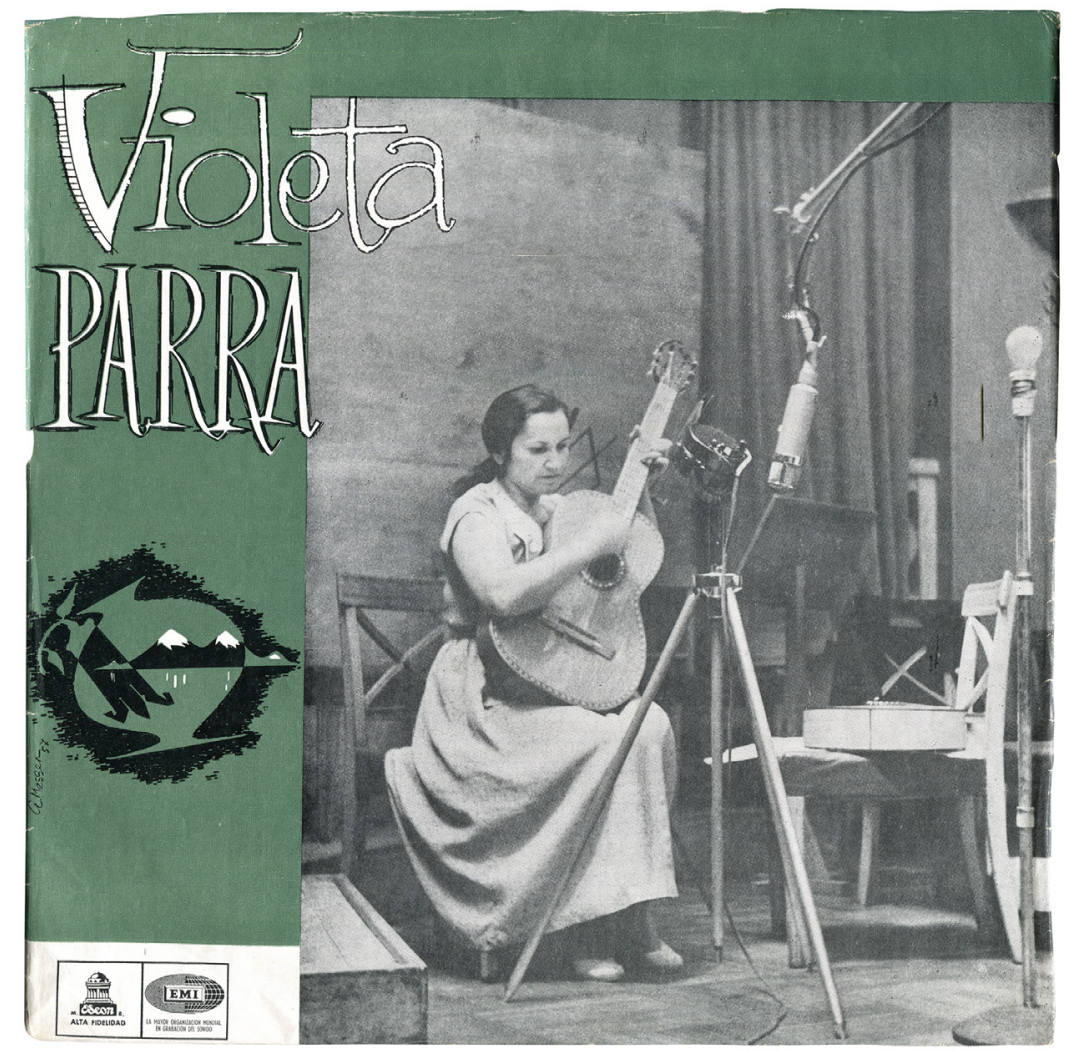

Éste es el volumen 1 de la colección El folklore de Chile, que alcanzará 30 volúmenes, cinco de los cuales están dedicados a la música de Violeta Parra. La colección se forjó a instancias del productor musical Rubén Nouzeilles. El tema final del disco, la mazurca "La paloma ingrata", fue aprendido por Violeta de su padre. El tema "Verso por la niña muerta"* está dedicado a su malograda hija Rosita Clara. 
2.6. Violeta Parra: "Verso por despedida a Gabriela Mistral"* y "Verso por el padecimiento de Gabriela”* (1957)

Odeon 87-045, disco de acetato 10" 78 RPM

En este disco nombra a la Nóbel como "Grabiela", le compone un "canto a lo divino" y la santifica.

\subsection{Composiciones para guitarra (1957)}

Odeon MSOD/E-51020, EP 10" 45 RPM, Chile.

Contiene lado A: "El joven Sergio"*, "Canto a lo divino"*, "Anticueca n. ${ }^{\circ} 1$ "*. Lado B: "Anticueca n. ${ }^{\circ}$ "*, "Tres palabras"*, "Travesuras"*.

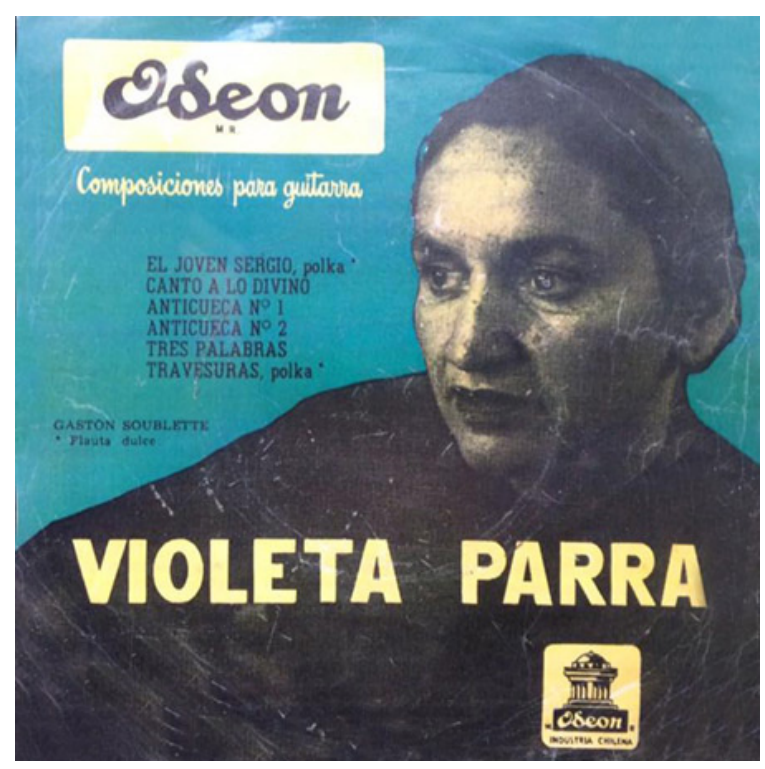

En estas composiciones Violeta demuestra su virtuosismo en la interpretación de la guitarra con piezas todas de su autoría. La acompaña en un par de temas Gastón Soublette en flauta dulce.

El tema "El joven Sergio"* está dedicado a Sergio Larraín, autor de varias fotografías para el libro de Violeta Parra Cantos folklóricos chilenos.

Además de las dos anticuecas de este disco, Violeta Parra compuso “Anticueca 3", "Anticueca 4" y "Anticueca 5", temas que fueron gra- 
bados por Miguel Letelier en 1960 y editados póstumamente en cedé. ${ }^{5}$ Ciertamente el término "anticueca" es un símil del término "antipoesía" propendido por su hermano Nicanor.

\subsection{El folklore de Chile volumen 2 (1958)}

Odeon LDC-36025, LP 12” 331/3 RPM, Chile.

Contiene lado A: "Verso por el rey Asuero", “Adiós, corazón amante", "Bella joven", "Ya me voy a separar", "Verso por las doce palabras", "Viva Dios, viva la Virgen" ["Viva Dios"], "La muerte con anteojos"*, "Niña hechicera". Lado B: "Cueca larga de los Meneses" (letra de Nicanor Parra, música de Violeta Parra), "Amada prenda", "Verso por desengaño"*, "La petaquita”, "Tonada del medio", "Verso por padecimiento", “Tonada por ponderación", "Yo también quiero casarme".

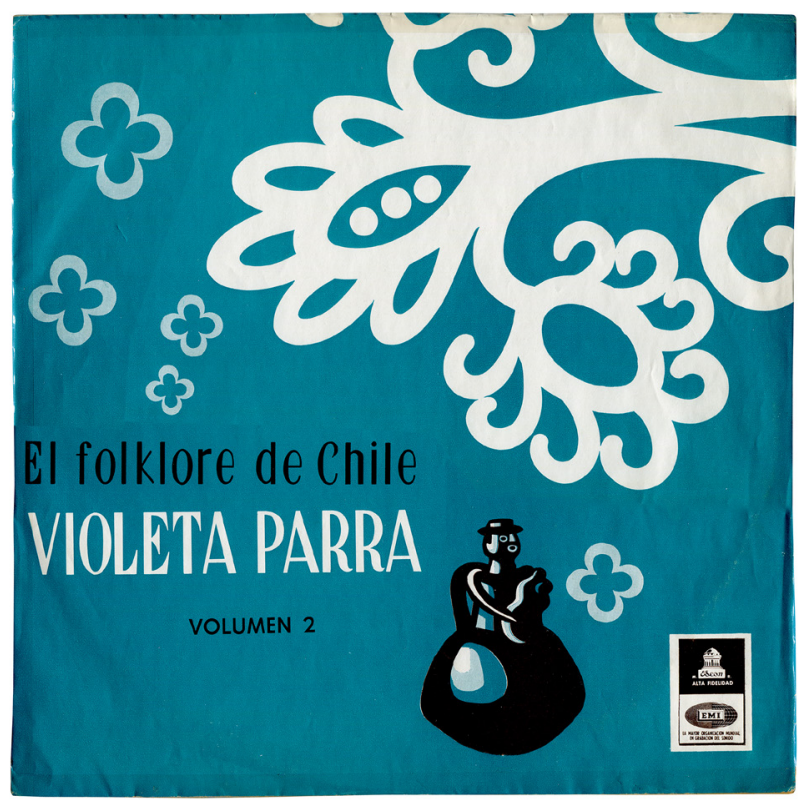

Éste es el volumen 2 de la colección El folklore de Chile. La portada es de Julio Escámez, pintor que incluyó a Violeta Parra como uno de los personajes de su mural Historia de la medicina y la farmacología en Chile (1957) para la otrora farmacia Maluje de Concepción. Julio Escámez es también autor de unas fotografías de Violeta Parra acompañada

${ }^{5}$ Composiciones para guitarra (1999). Warner Music Chile 8573 80701-2. 
de Pablo de Rokha, tomadas con una cámara que le regaló la misma Violeta. En la contratapa del disco hay comentarios de Raúl Aicardi, a quien Violeta consideraba "el mejor director de radio, sin discusión ninguna". 6

El disco incluye la musicalización a la primera parte del poema de su hermano Nicanor "La cueca larga", denominada aquí como "Cueca larga de los Meneses".

\subsection{La cueca presentada por Violeta Parra (1959) ${ }^{7}$}

Odeon LDC-36038, LP 12" 3311/3 RPM, Chile.

Contiene lado A: "Presentación y comentario inicial"*, "La cueca del balance", "Adiós, que se va Segundo", "Floreció el copihue rojo", "Un viejo me pidió un beso", "Cueca del organillo", "Cuando estaba chiquillona", "Una chiquilla en Arauco", "Quisiera ser palomita", "En el cuarto de la Carmela", "La muerte se fue a bañar", "De las piernas de un zancudo", "Dame de tu pelo rubio". Lado B: "Comentario"*, "Yo vide llorar a un hombre", "Tengo de hacer un retrato", "Pañuelo blanco me diste", "Cueca del payaso", "La mariposa", "Para qué me casaría", "Cueca valseada", "La niña que está bailando", "Cueca de armónica", "El ají ma’úro", "En la cumbre de los Andes", "Cueca larga de los Meneses (2 pie)" (letra de Nicanor Parra, música de Violeta Parra), "Palabras finales"*.

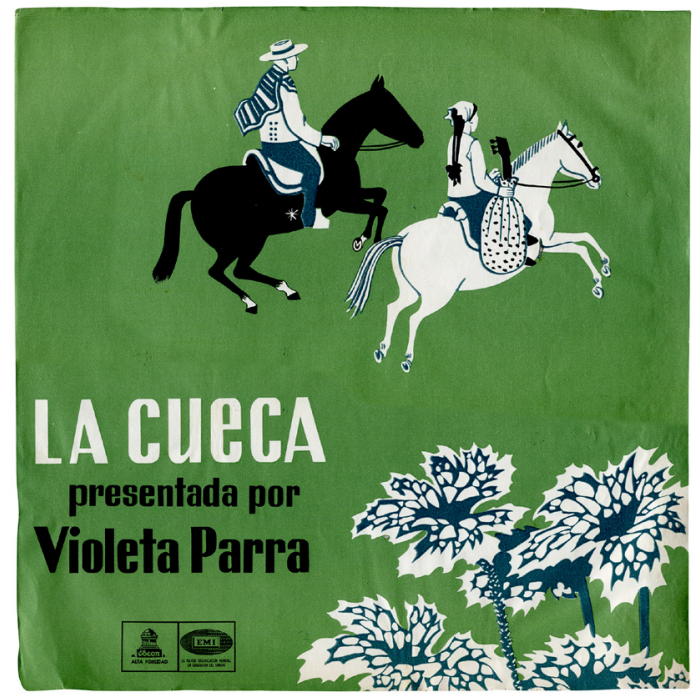

${ }^{6}$ García, Violeta Parra, 15-16.

${ }^{7}$ Agradezco a Sandra Piñeiro y Jaime Bristilo por haberme obsequiado el disco La cueca. 
Éste es el volumen 3 de la colección El folklore de Chile y el primer LP de cuecas de la industria musical chilena. Como su disco anterior, la portada es obra de Julio Escámez. Se incluye la segunda parte de la musicalización al poema de su hermano Nicanor "La cueca larga", denominada como "Cueca larga de los Meneses $\left(2^{\circ}\right.$ pie)".

\subsection{La tonada presentada por Violeta Parra (1959)}

Odeon, LP 12" 331/3 RPM, LDC-36054, Chile.

Contiene lado A: "¿Adónde vas jilguerillo?", "Atención mozos solteros", "Cuando salí de mi casa", "Si lo que amo tiene dueño”, “Cuándo habrá cómo casarse?", "Un reo siendo variable", "Si te hallas arrepentido". Lado B: "Las tres pollas negras", "Una naranja me dieron", "Huyendo voy de tus rabias", "El joven para casarse", "Tan demudado te he visto", "Yo tenía en mi jardín", "Imposible que la luna", "Blanca Flor y Filumena".

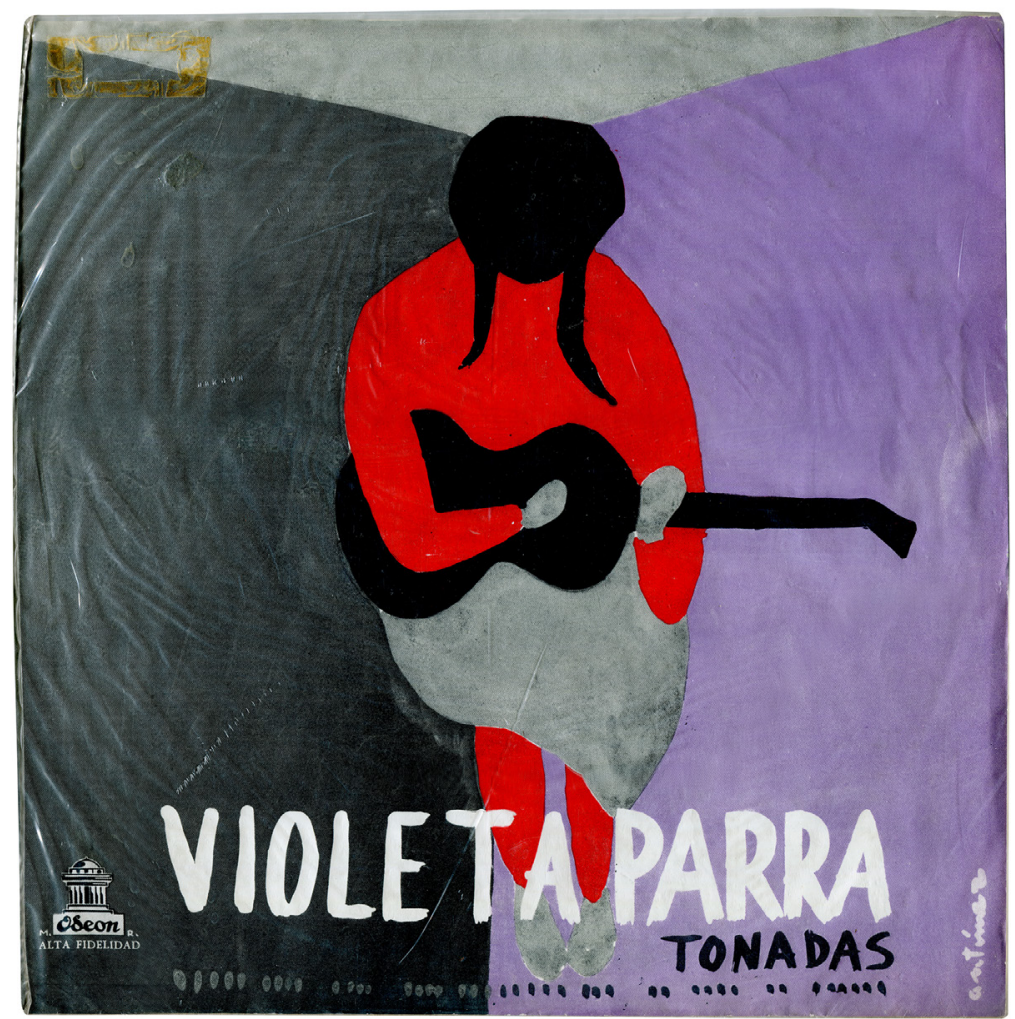


Éste es el volumen 4 de la colección El folklore de Chile. Ilustración de portada de Nemesio Antúnez, a quien le dedicara su composición nunca grabada "Los manteles de Nemesio".

En la contraportada se reproduce una cuarteta de Nicanor Parra, una cuarteta de Pablo Neruda y unas palabras de Nemesio Antúnez.

En el centro de la mar

Suspiraba una guitarra

Y en el suspiro decía

Que cante Violeta Parra

(Nicanor Parra)

...entró Violeta Parrón

violeteando la guitarra,

guitarreando el guitarrón,

entró la Violeta Parra...

(Pablo Neruda)

Violeta!!!

Te hice el dibujo con un pie en el estribo del avión - espero que te guste.

Cariños

$\mathrm{N}$.

(Nemesio Antúnez)

Fotografía de Violeta Parra en contraportada fue captada por Sergio Bravo. En el tema "Si te hallas arrepentido", Violeta Parra hace la primera y segunda voces. Todas las canciones del disco son del folclor; "Adónde vas jilguerillo" fue aprendida de su madre, Clarisa Sandoval.

\subsection{Fiesta chilena, volumen 4 (1959)}

Odeón LDC-36076, LP 12”331⁄3 RPM, Chile.

Cuarto volumen de una antología de música chilena en la que se incluye a varios intérpretes. Este volumen es el único de la serie que trae un tema inédito de Violeta Parra: "Vente, niña"*. 


\subsection{Toda Violeta Parra (1961)}

Odeon LDC-36344, LP 12" 331주 RPM, Chile.

Contiene lado A: "Hace falta un guerrillero"*, "Veintiuno son los dolores"*, "Por la mañanita"*, "El día de tu cumpleaños"*, "El Chuico y la Damajuana" (letra de Nicanor Parra, música de Violeta Parra), "Yo canto la diferencia"*, "El hijo arrepentido" (letra de Nicanor Parra y música de Violeta Parra). Lado B: "Amigos tengo por ciento"*, "Por pasármelo toman..."* ["Por pasármelo tomando"], "Qué te trae por aquí", "Casamiento de negros" (del folclor chileno / Violeta Parra), "El pueblo" ["Paseaba el pueblo sus banderas rojas"] (letra de Pablo Neruda y música de Violeta Parra), "La jardinera"*, "Puerto Montt está temblando"*.

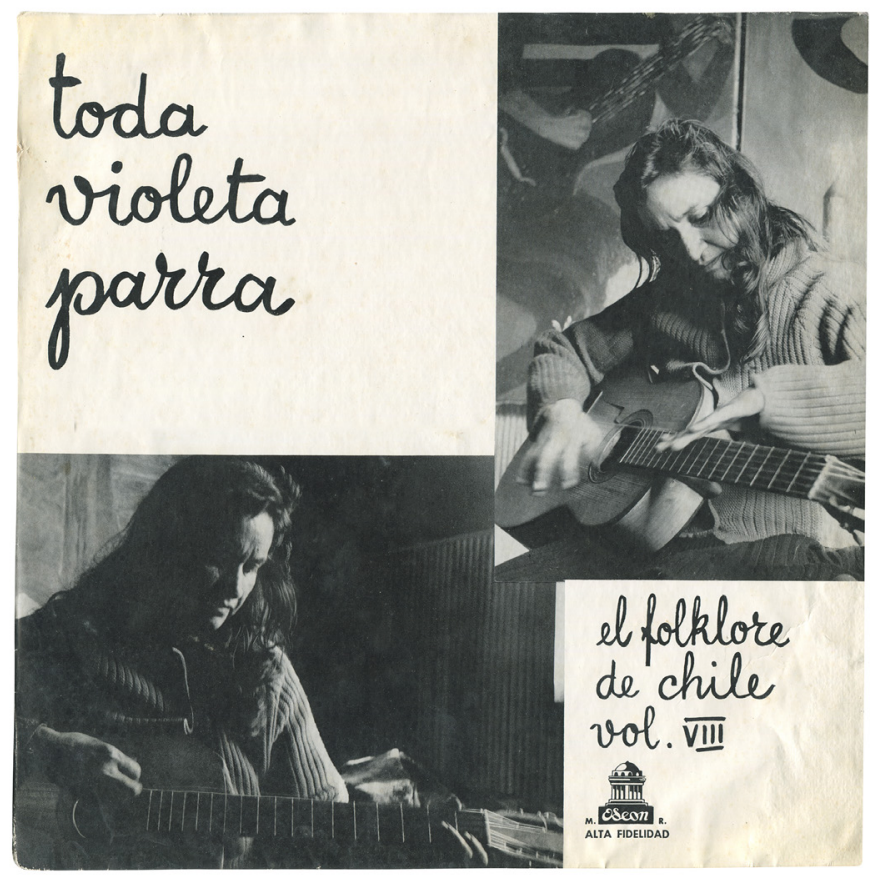

Volumen 8 de la colección El folklore de Chile. Fotos de Fernando Krahn. "El día de tu cumpleaños"* está dedicado a Enrique Bello Cruz; "Por pasármelo toman..."*, a su hermano Roberto. Violeta Parra participa en la composición de todos los temas. Musicaliza un poema de Pablo Neruda - "El pueblo", de Canto general (1950) — y dos poemas de Nicanor Parra - "El Chuico y la Damajuana", de La cueca larga (1958), y "El hijo arrepentido", que nunca salió en libro-. 


\subsection{El folklore de Chile según Violeta Parra (1962)}

Odeon LDI-503, LP 12" 331/3 RPM, Argentina.

Contiene lado A: "Qué pena siente el alma", "La pericona dice", "Salga el sol, salga la luna", "La mazamorrila de cuatro pies", "A cantarle a los porté..."*, "Levántate, Huenchullán"* ["Arauco tiene una pena"], "Cantaron los pajaritos". Lado B: "Arriba quemando el sol”*, "Parabienes al revés", "Cristo cuando vino a "nuestro", "Vengo toda avergonzada" ["Señores y señoritas"], "Según el favor del viento"*, "Una flor voy a nombrar", "A la una nací yo" ["A la una"].

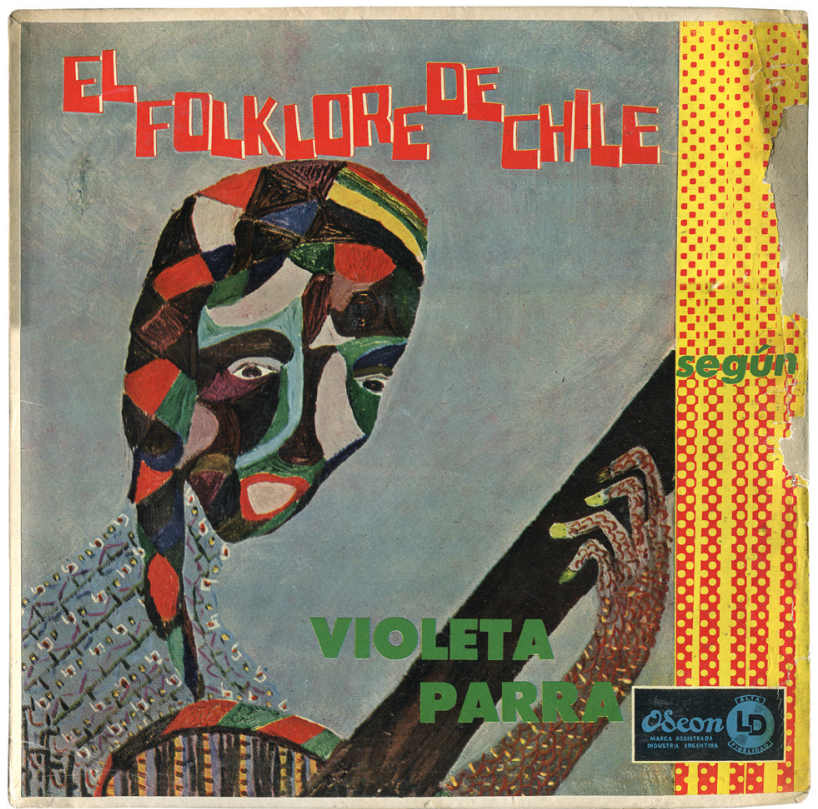

La ilustración de la portada es un autorretrato en óleo de Violeta Parra, y ésta es su primera producción discográfica en la que se ocupa una obra visual suya. Comentarios de la contratapa de Raúl Aicardi (reproducidos antes en Violeta Parra, canto y guitarra) y Gastón Soublette (reproducidos antes en Toda Violeta Parra).

Violeta Parra hace la primera y segunda voces en "Una flor voy a nombrar". Algunas publicaciones establecen que en este disco habría venido su canción "Por qué los pobres no tienen"*, hecho por el cual habría sido censurado, pero no se conocen grabaciones de aquella canción interpretada por su autora. 


\subsection{Chants et danses du Chili (1964)}

Le Chant du Monde LD-S-4271, LP 10"331⁄3 RPM, Francia.

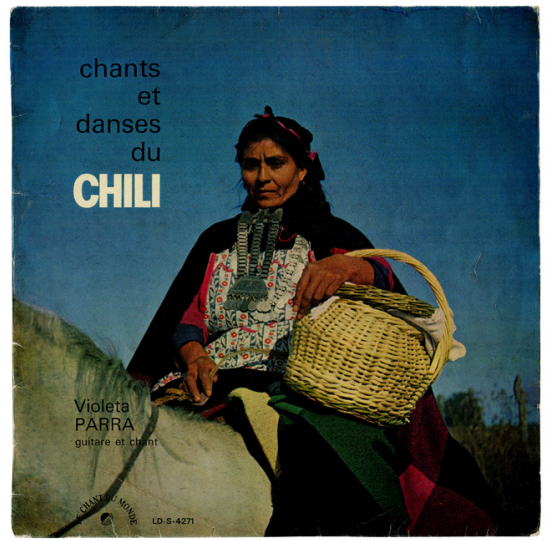

Compilación de sus dos primeros EP franceses de 1956 (ver ítem 2.4), aunque se excluyen "Qué pena siente el alma"*, "La jardinera"* y "A Lulu".

La edición fue motivada por su asistencia a la exposición en 1964 de sus obras visuales en el pabellón Marsan del Musée des Arts Décoratifs del Louvre.

\subsection{Recordando a Chile (1965)}

EMI-Odeón LDC-36533, LP 12" 331조 RPM, Chile.

Contiene lado A: "Defensa de Violeta Parra" (Nicanor Parra), "Mañana me voy pa'l norte"*, "Qué he sacado con quererte"*, "El diablo en el paraíso"*, "A la una nací yo" ["A la una"], "Une chilienne à Paris"*. Lado B: "Paloma ausente"*, "Arriba quemando el sol"* ["Y arriba quemando el sol"], "Julián Grimau"* ["Qué dirá el Santo Padre"], "Pedro Urdemales", "Écoutemoi, petit"*.

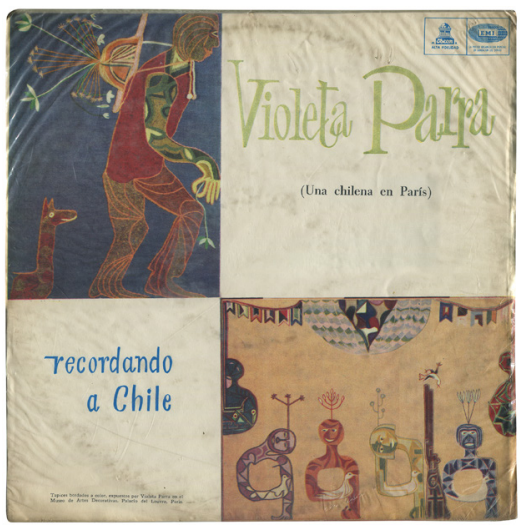


En la portada aparecen detalles de dos arpilleras de Violeta Parra: "Le clown" y "Contre le guerre", que fueron expuestos en su exposición en el Louvre. Texto de contraportada de Enrique Bello Cruz.

El primer tema es la recitación del poema "Defensa de Violeta Parra" en la voz de su hermano Nicanor, acompañada por Violeta en la guitarra. El poema aparecerá publicado en el libro de Nicanor Parra Obra gruesa (1969), en cuya versión se agregan algunos versos al final. La canción "Paloma ausente" está dedicada a su hija Carmen Luisa. Aparecen dos temas en francés compuestos por Violeta Parra.

El sello cambia de nombre de Odeon a EMI-Odeon.

\subsection{Süd- und Mittelamerikanische Volksmusik (1965)}

Eterna 830014, LP 12”331⁄3 RPM, República Democrática Alemana.

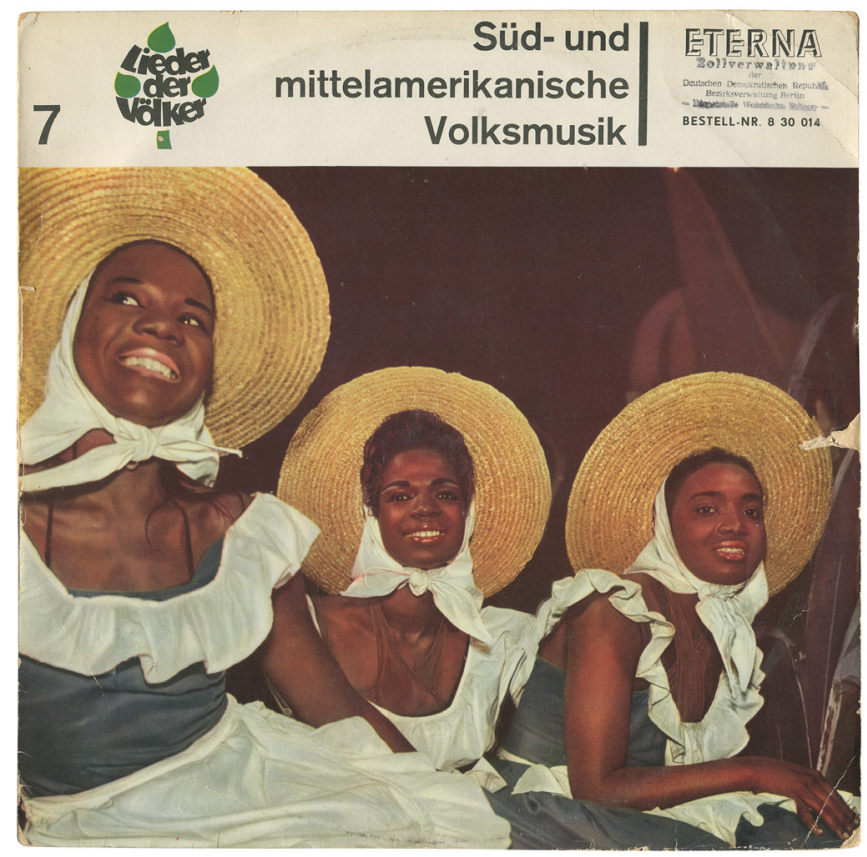

El disco incluye música de Chile, Brasil y México. Chile está representado por "Violeta Parra Sandoval und ihre Gruppe", con grabaciones hechas en ese país durante 1962. La presentación de contratapa fue escrita por Jürgen Elsner. 
El lado A concluye con el conjunto chileno interpretando "Del norte vengo, Maruca" (Ángel Parra), "Casamiento de negros" (del folclor chileno / Violeta Parra) y "Las gatas con permanente" ["Ya se fue el mes de agosto"] (Roberto Parra). Y el lado opuesto empieza con tres de las canciones políticas más notables compuestas por Violeta Parra: "Miren cómo sonríen"* e "Y arriba quemando el sol"*, cantadas por ella misma, y "Por qué los pobres no tienen"*, en la voz de su hija Isabel.

\subsection{Carpa de La Reina (1966) ${ }^{8}$}

EMI-Odeon LDC-36581, LP 12”331/3 RPM, Chile.

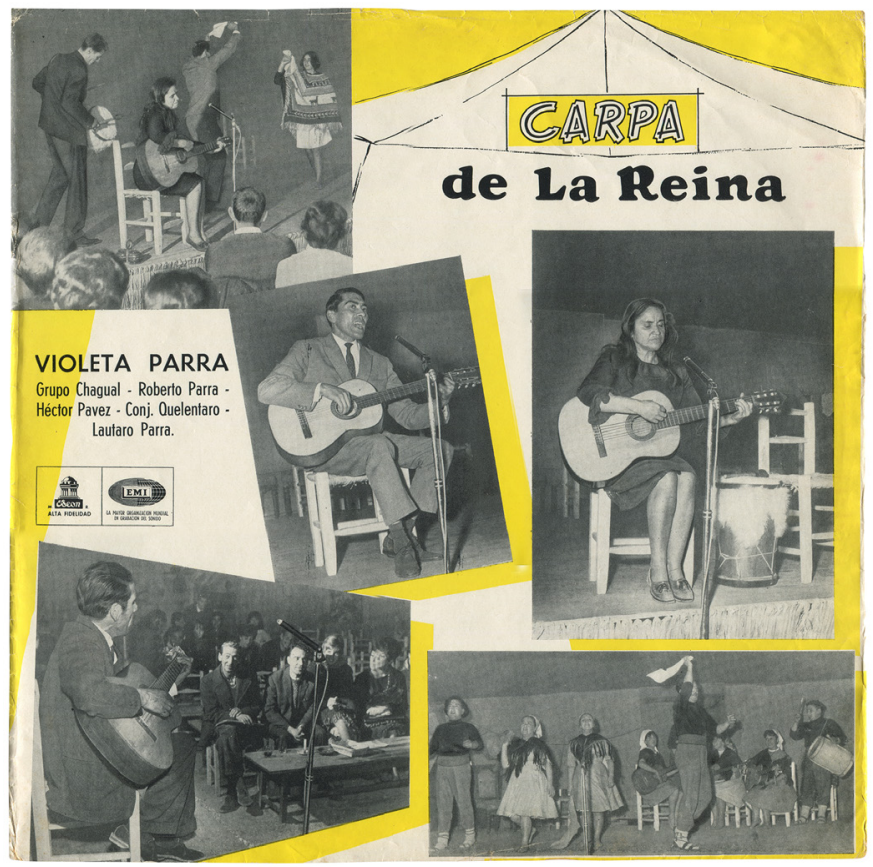

El disco publicitaba su proyecto "Carpa de La Reina", una carpa para encuentros folclóricos — principalmente musicales-, ubicada en la comuna de La Reina.

En el disco, además, participan su hermano Roberto, su hermano Lautaro, el Conjunto Quelentaro, Héctor Pavez y la agrupación Chagual, quienes formaban parte del elenco de la Carpa de La Reina.

${ }^{8}$ Agradezco a Paola Miño y Cristián Kirby por haberme obsequiado el disco Carpa de La Reina. 
Violeta Parra interpreta los siguientes temas, todos de su autoría: "La pericona se ha muerto"*, "Se juntan dos palomitas"*, "Los pueblos americanos"* y "Palmero, sube a la palma"*. Conjunto Quelentaro interpreta la canción recopilada por Violeta Parra "Atención mozos solteros". Y Chagual interpreta "Corazón maldito"*, uno de los temas más conocidos de Violeta a pesar de nunca haberlo grabado.

\subsection{Las últimas composiciones de Violeta Parra (1966)} RCA Victor CML-2456, LP 12" 331/3 RPM, Chile.

Contiene lado A: "Gracias a la vida"*, "El "Albertío"”, "Cantores que reflexionan"*, "Pupila de águila"*, "Run-Run se fue pa'l norte"*, "Maldigo del alto cielo"*, "La cueca de los poetas" (letra de Nicanor Parra y música de Violeta Parra). Lado B: "Mazúrquica modérnica"*, "Volver a los diecisiete"*, "Rin del angelito"*, "Una copla me ha cantado"*, "El guillatún"*, "Pastelero, a tus pasteles"*, "De cuerpo entero"*.

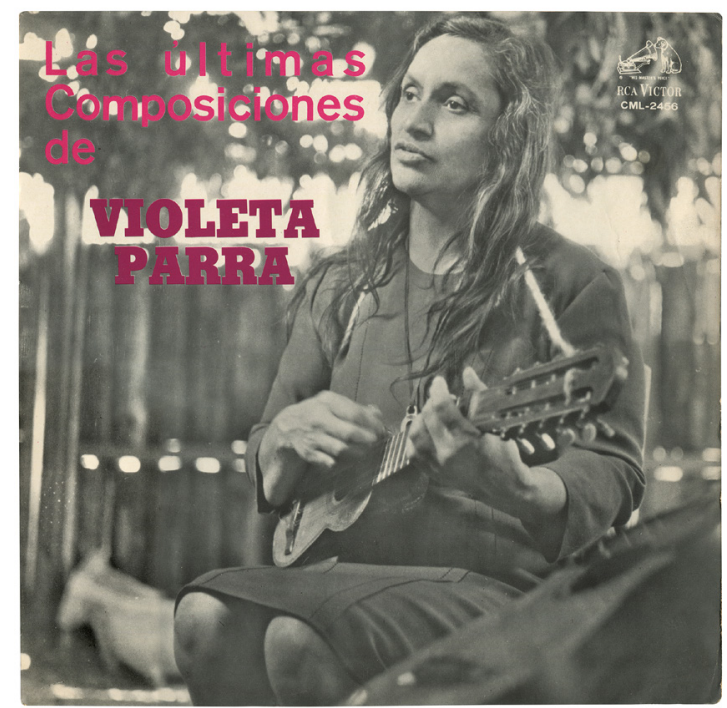

Considerado el mejor álbum de la música chilena, incluye las composiciones más célebres de Violeta Parra: "Gracias a la vida"*, "Volver a los 17 "* y "Run-Run se fue pa'l norte"*.

Algunas canciones las interpreta a dúo con Alberto Zapicán, el mismo a quien está dedicado "El 'Albertío"”*. En la instrumentación — guitarra, guitarrilla, charango y bombo- colaboraron sus hijos Isabel y Ángel. A Violeta Parra le gustaba denominar "guitarrilla" al cuatro venezolano. 
La fotografía de portada es de Javier Pérez.

Violeta Parra decide cambiar de sello para publicar sus últimas composiciones y vuelve al sello musical de sus comienzos RCA Victor.

Tuvo dos ediciones estatales: ${ }^{9}$ una intervenida por un cuarteto de violines con arreglos de Nino García y otra en la que se suprimen "Maldigo del alto cielo"* y "Mazúrquica modérnica"*.

\section{DISCOGRAFÍA PÓSTUMA}

\subsection{Canciones reencontradas en París (1971)}

Dicap DCP 22, LP 12" 331/3 RPM, Chile.

Contiene lado A: "Santiago, penando estás"* ["Mi pecho se halla de luto"], "Según el favor del viento"*, "Arauco tiene una pena"* ["Levántate, Huenchullán"], "Hasta cuándo está"* ["Hasta cuándo"]. Lado B: "La carta”* ["Los hambrientos piden pan"], "Qué vamos a hacer (Ayúdame Valentina)"*, "Es una barca de amores"*, "Rodríguez y Recabarren"* ["Un río de sangre corre"].

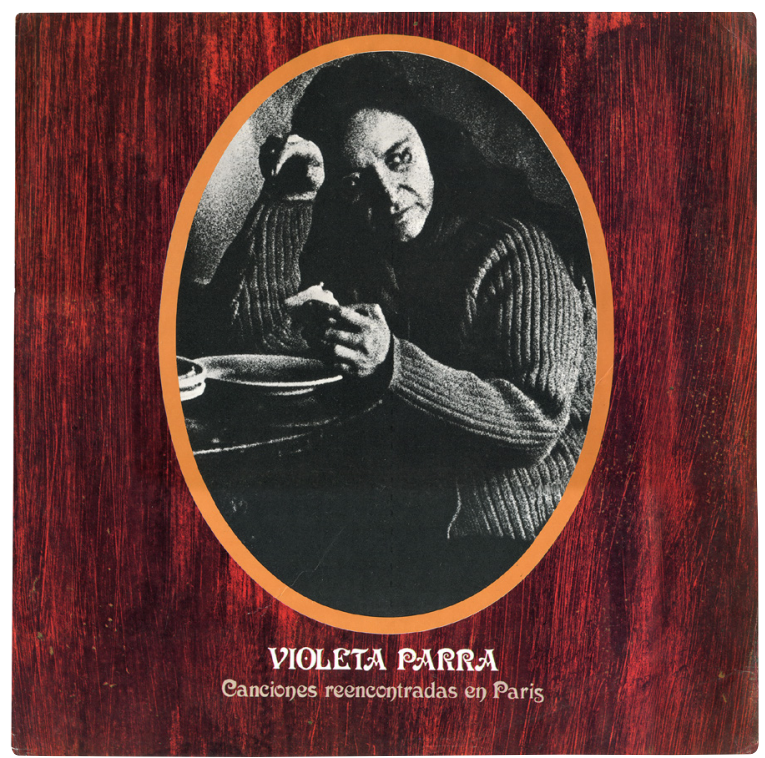

El sello discográfico Dicap (Discoteca del Cantar Popular) tuvo en su catálogo mayoritariamente a exponentes del movimiento Nueva Canción Chilena.

\footnotetext{
${ }^{9}$ RCA Victor fue expropiado durante la Unidad Popular.
} 
Estas grabaciones fueron hechas para el sello francés Arion en 1963 y fueron compartidas a su hija Isabel Parra en 1970 después de que se las hiciera escuchar la directora del sello, Ariane Segal.

Fotografía de portada de Fernando Krahn, tomada el año 1960 en casa de Violeta. Diseño del disco de Vicente y Antonio Larrea. Comentario en la contratapa de Héctor G. Miranda, integrante de los Calchakis.

Violeta, estando en Francia en 1962, se entera de que durante una marcha es apresado su hermano Roberto, hecho que inspira su canción "La carta". A este hecho se suma la matanza en la población José María Caro, acontecida el mismo año.

\subsection{Un río de sangre (1974)}

Arion ARN 34222, LP 12" 331⁄3 RPM, Francia.

Aparecen dos canciones de sus hijos Ángel e Isabel, tomadas de su disco Au Chili avec los Parra de Chillan de 1963 (ver ítem 4.3), además de todos los registros de Canciones reencontradas en París de 1971 (ver ítem 3.1), aunque se agrega "Julián Grimau”* [“Qué dirá el Santo Padre"]. Se han eliminado de la grabación las estrofas donde se mencionan a Grimau y Lumumba.

\subsection{Violeta Parra presente... ausente... (1975)}

Le Chant du Monde LDX 74572/73, doble LP 12"331/3 RPM, Francia.

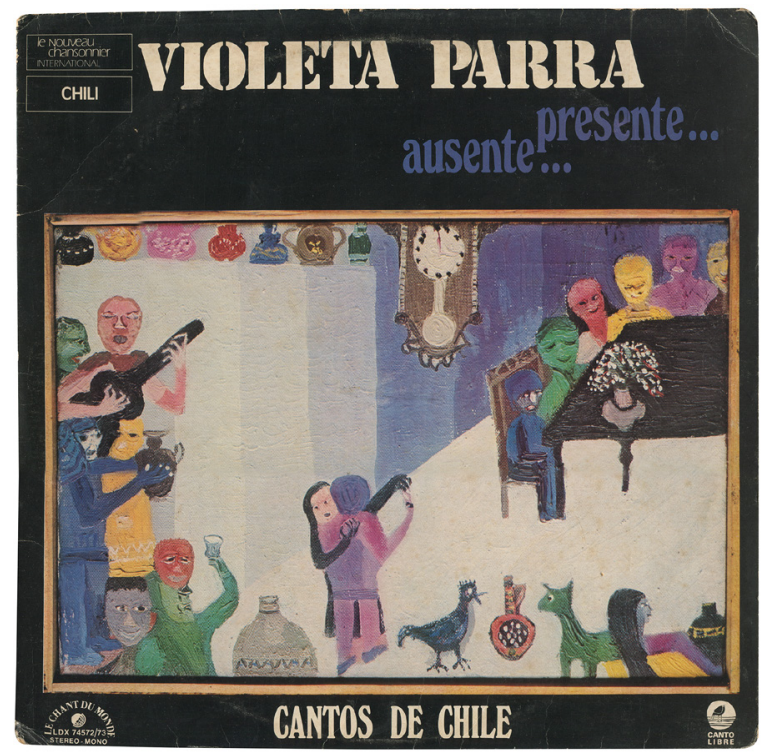


Álbum doble que incluye íntegramente sus dos primeros EP's franceses (ver ítem 2.4), más algunos temas que fueron descartados para esas producciones. En estos discos, se agrega la presentación que hace de cada tema la propia Violeta, que consiste en nombrar el título de la canción.

Los discos también incluyen una grabación de Violeta Parra, hecha en 1964 también en Francia, de la que se considera su obra mayor: "El gavilán"*, la canción más extensa de todas sus interpretaciones conocidas.

La portada del álbum incluye una reproducción de un óleo sobre tela de la propia Violeta Parra: "La fête chez Violeta" (La fiesta donde Violeta).

Las nuevas canciones que incluye el disco son: "Cantos a lo divino" ["Tres cantos a lo divino"], "Verso por ponderación", "Tres cuecas punteadas" ["Cuecas punteadas"], "Tres polcas antiguas" ["Tres polkas"], "Lágrimas de Carabaña" ["Los paires saben sentir"], "Violeta ausente"*, "Si te hallas arrepentido" ["Me voy, me voy"], "Dicen que el ají maduro" ["El ají ma'úro"], "Dónde estás, prenda querida", "Ojos negros y pardos" ["Ojos negros matadores"], "Aquí se acaba esta cueca", "El gavilán”*.

\subsection{Décimas (1978)}

Alerce, LP 331/3 RPM, ALP-204-A, Chile.

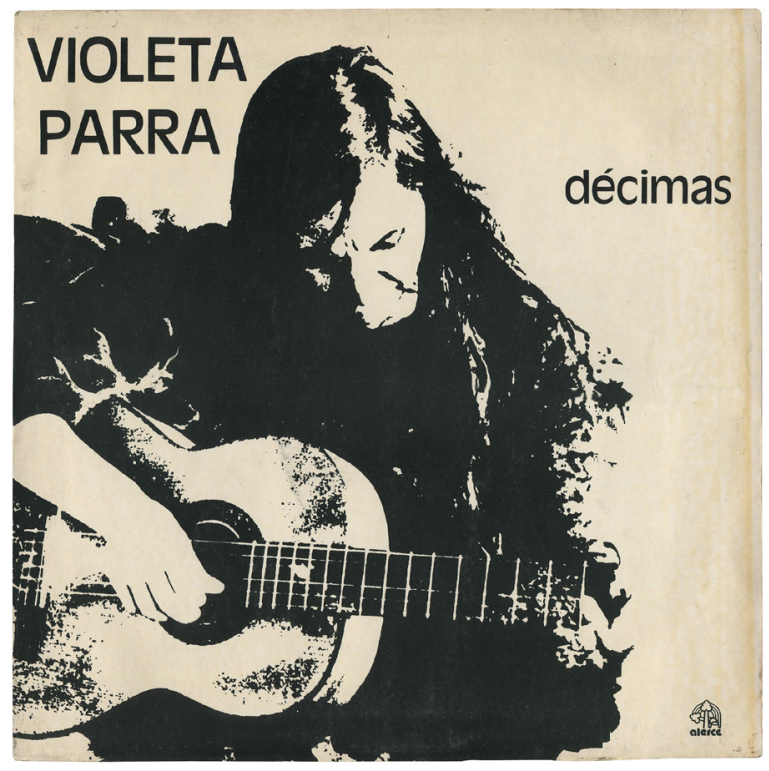


El disco incluye recitadas y acompañadas en guitarra las diez primeras composiciones de su libro Décimas, con mínimas variantes y un leve cambio de orden en las composiciones.

Décimas fue escrito durante 1957 y 1958, y estas grabaciones fueron hechas para Odeon entre 1964 y 1965.

La fotografía de portada es de José Muga. En la contratapa hay comentarios de Cristián Santa María y Ricardo García. Este último fue el fundador del sello Alerce en 1975, y trabajó como libretista del programa radial "Canta Violeta Parra", de Radio Chilena entre 1953 y 1954, que logró tal popularidad que Violeta obtuvo el Premio Caupolicán a la mejor folclorista en 1954.

Ricardo García fue, además, quien bautizó como Nueva Canción Chilena al movimiento de renovación musical latinoamericanista surgido en el país durante la década del 60; a Violeta Parra se la considera inspiradora e influencia de este movimiento.

\subsection{Violeta Parra, volumen 3 (1977)}

\section{EMI-Odeon 058-440311, LP 12" 3313/3 RPM, Chile.}

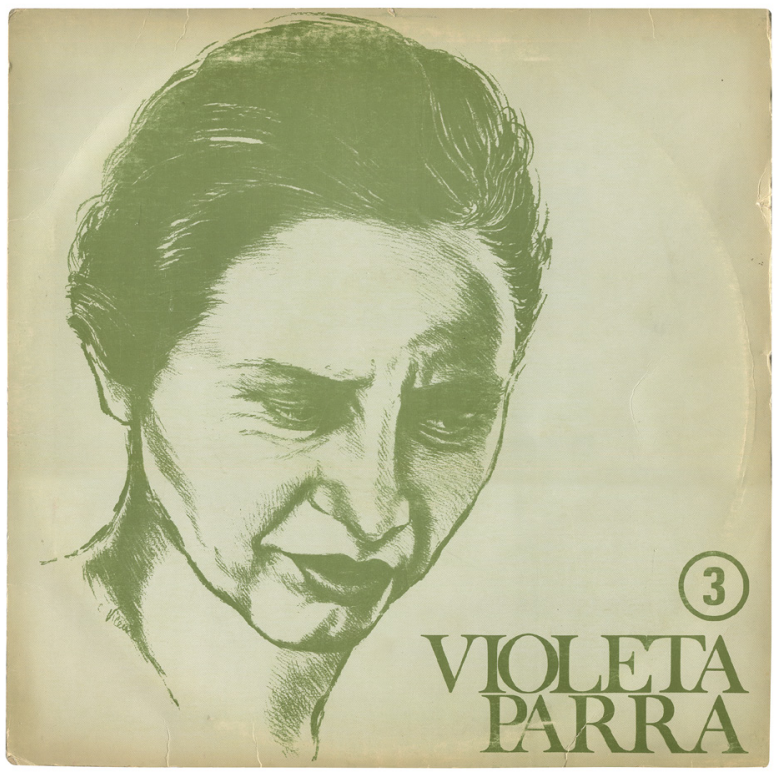

Tercer volumen de una antología de cuatro discos, cuya selección de temas estuvo a cargo de Miguel Cárcamo M. 
Este volumen es el único de los cuatro que trae temas inéditos por Violeta Parra: "Los mandamientos" ["Escucha, vidita mía"] y "El huaso Perquenco" (letra tradicional, música de Violeta Parra).

En los créditos del disco se establece que "El huaso Perquenco" es una recopilación de Violeta Parra, pero la folclorista Gabriela Pizarro, en su libro Cuaderno de terreno: apuntes sobre el romance en Chile (1987), aclara que:

Violeta tomó el texto de este romance de la colección de Julio Vicuña Cifuentes, Romances populares y vulgares, editado en 1912, y le puso música.

Le atrajo, tal vez, esta sintética interpretación de un bandido campesino chileno, legendario o no, habitante de lo que una vez fuera "la frontera" desplazada sucesivamente hacia el Sur. ${ }^{10}$

En la grabación de Violeta Parra, al texto se agrega una sílaba métrica que falta en la versión recopilada por Vicuña Cifuentes.

\subsection{Temas inéditos. Homenaje documental (1987)}

Mandioca MSD-016, EP 7” 45 RPM, Argentina.

Contiene lado A: "Arriba quemando el sol"*, "Según el favor del viento"*. Lado B: "Hace falta un guerrillero"*, "Miren cómo sonríen"*.

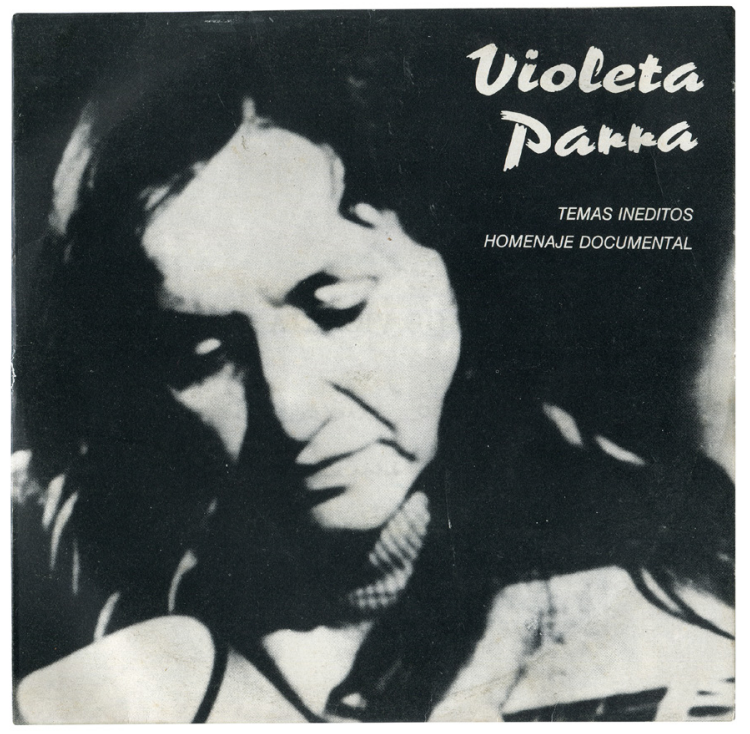

${ }^{10}$ Gabriela Pizarro, Cuaderno de terreno: apuntes sobre el romance en Chile (Santiago: Autoediciones Populares / Taller Lican-Rumi, 1987), 82. 
El disco fue publicado por el sello Mandioca, casa discográfica abocada al rock argentino. Éste es uno de los tantos discos míticos del sello. Fue grabado por Noberto Folino en la habitación del hotel Phoenix donde se alojaba Violeta Parra en una visita a Buenos Aires en 1962.

\section{COLABORACIONES CON OTROS INTÉRPRETES}

\subsection{Isabel Parra, "La sentencia"* y "La celosa" (1957)}

Odeon 87-056, disco de acetato 10", 78 RPM, Chile.

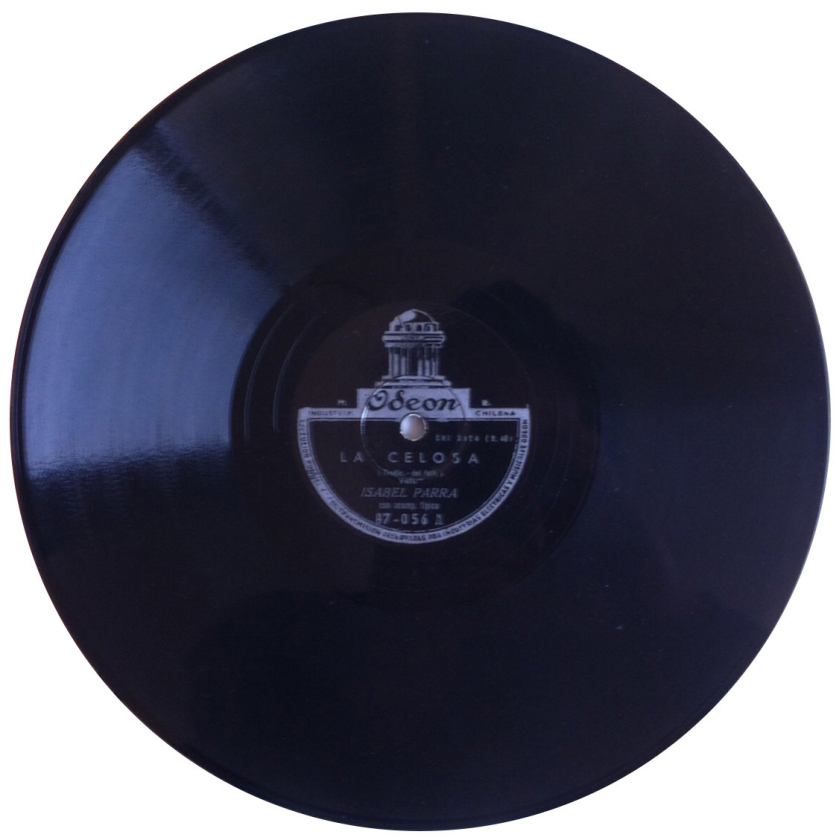

Violeta Parra colaboró principalmente con su hija Isabel. Y, a su vez, Isabel fue la intérprete que más colaboró con Violeta Parra.

Y su primer disco solista, Isabel Parra lo hace también al compás de su progenitora. Interpreta ahí un tema compuesto por su madre, "La sentencia"*, y un tema recopilado por su madre, "La celosa", que según Roberto Parra fue una de las primeras canciones que aprendió Violeta en su infancia. ${ }^{11}$

${ }^{11}$ Roberto Parra, Vida pasión y muerte de Violeta Parra (Santiago: Ediciones Tácitas, 2017), segunda edición, 93-94. 


\subsection{Roberto Parada, La cueca larga (1960)}

Editorial Universitaria, EP 7" 45 RPM, Chile.

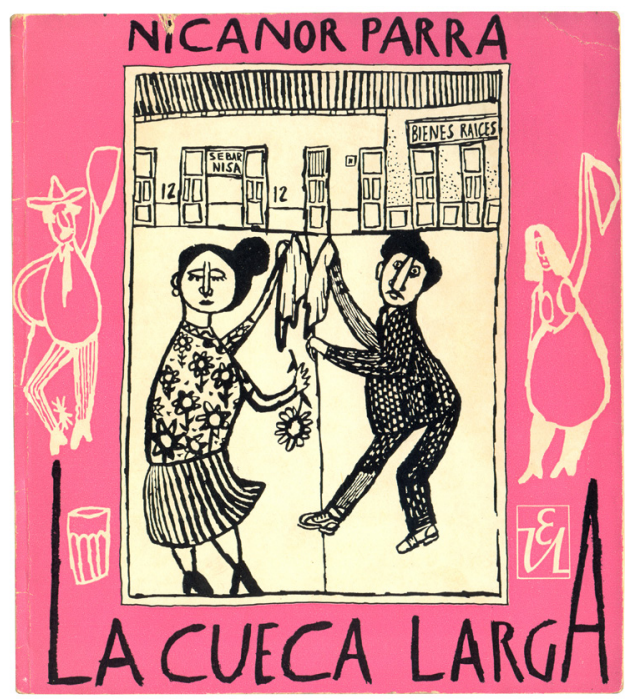

Recitación del libro de Nicanor Parra La cueca larga (1958), en la voz del actor Roberto Parada y acompañamiento en la guitarra de Violeta Parra.

Portada de Nemesio Antúnez, muy similar a la estética del libro original, al que también hizo su portada e ilustraciones interiores.

\subsection{Isabel y Ángel Parra, Au Chili avec los Parra de Chillan (1963)} Barclay 86.078, LP 10", 331⁄3 RPM, Francia.

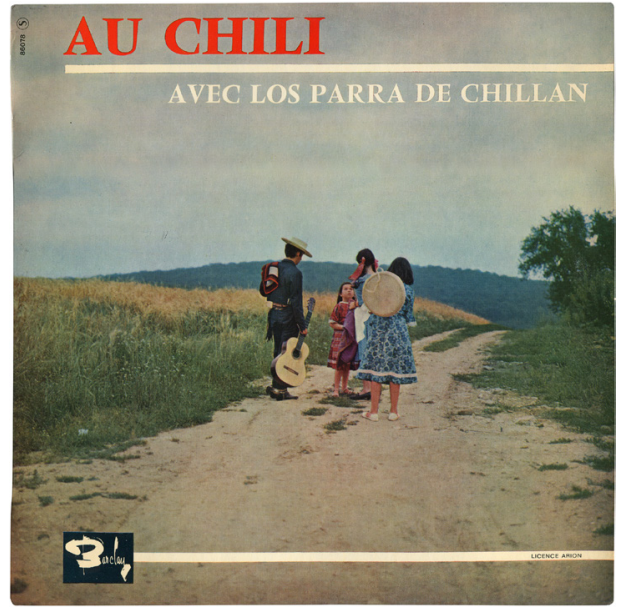


Violeta participa en algunas canciones animando, percutiendo o tocando la guitarra. En el disco, sus hijos interpretan las canciones de su madre "Diez y seis de julio"*, ${ }^{12}$ y "Parabienes al revés"*.

\subsection{Violeta e Isabel Parra, "Ven acá, regalo mío"* y "En los altos de} Colombia" (1964)

Demon SD-055, Single 7" 45 RPM, Chile.

La cueca "En los altos de Colombia" la aprendió Violeta Parra de su madre, Clarisa Sandoval.

\subsection{Toute l'Amérique Latine (1965)}

Barclay 820.005, LP 12" 331⁄3 RPM, Francia.

Antología promocional en la que aparecen varios músicos latinoamericanos del catálogo del sello. Entre ellos, el europeo Gilbert Favre interpreta en quena el tema de Violeta Parra "Cachimbo"*; en el bombo lo acompaña la autora y en el pandero, Isabel Parra.

\subsection{El tocador afuerino y Violeta Parra (1966)}

EMI-Odeon MSOD/E-51029, EP 7" 45 RPM, Chile.

Contiene lado A: "El moscardón"* ["Cueca para flauta y tambor"], "Galambo temucano"* ["Galambito temucano"]. Lado B: "Tocata y fuga"* ["Los mapuches"], "Camanchaca"*.

El tocador afuerino es Gilbert Favre, quien será el quenista del conjunto boliviano Los Jairas.

\subsection{Tita Parra, "El Manuelito chileno" (Ángel Parra) y "Qué tanto será"* (1966) \\ Demon SD-0164, Single 7" 45 RPM, Chile.}

Violeta colabora en 1966 en un disco de su nieta Tita Parra, en el que viene un tema suyo: "Qué tanto será"*. Ésta es la última grabación que hizo en vida.

${ }^{12}$ La grabación de este tema por Violeta Parra apareció póstumamente en el casete Violeta Parra 6 (EMI-Odeon 440586 4) con el título "Vuela, palomita". 
4.8. Roberto Parra, Las cuecas de Roberto Parra (1967)

EMI-Odeón LDC-36259, LP 12"331/3 RPM, Chile.

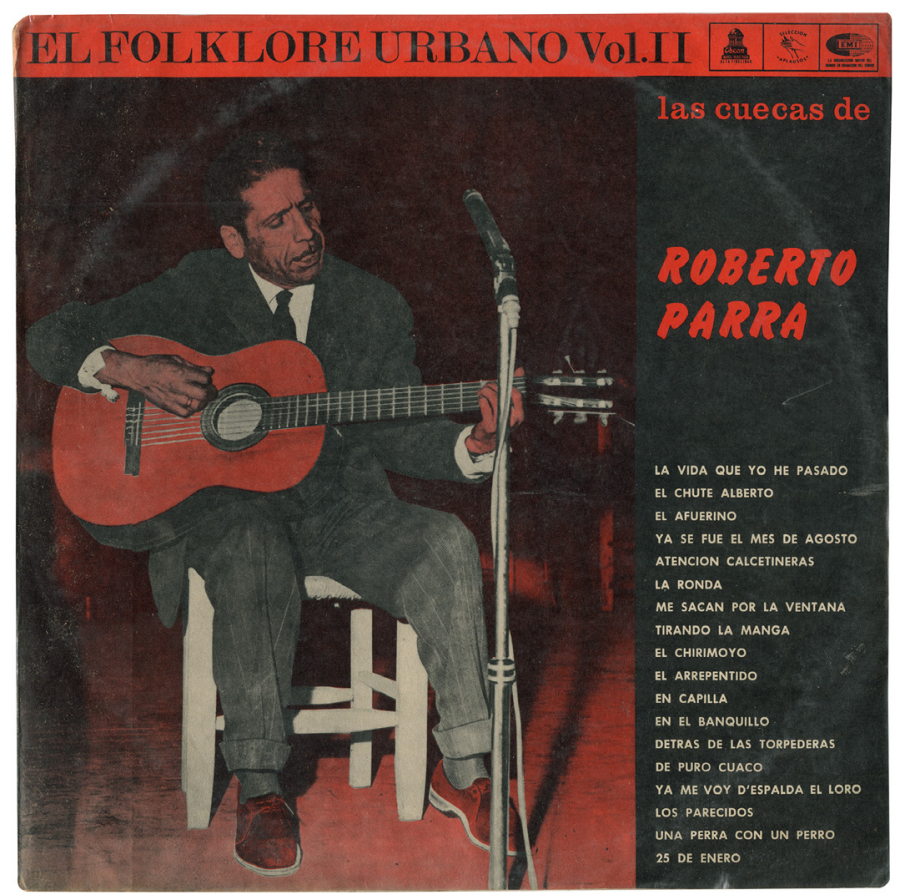

Todas las cuecas son de Roberto Parra. Violeta Parra lo acompaña en algunos temas en la animación, en los silbidos y en la percusión en tarro. "Violeta en los tarros, con lo cual no se rebaja su calidad artística, todo lo contrario; a ella le gustaban sus cuecas en tarro", dejó escrito Roberto Parra. ${ }^{13}$

El disco fue grabado en 1965, pero fue distribuido después de fallecida Violeta Parra.

${ }^{13}$ Roberto Parra, Las cuecas del Tío Roberto (Santiago: Autoediciones Populares / Taller Lican-Rumi, 1989), 19. 


\section{BIBLIOGRAFÍA CITADA Y CONSULTADA}

Alcalde, Alfonso. Toda Violeta Parra. Buenos Aires: Ediciones de la Flor, 1974.

García, Marisol, ed. Violeta Parra en sus palabras. Entrevistas (1954-1967). Santiago: CIP UDP / Catalonia, 2017.

Larrea, Antonio. 331/3RPM. Santiago: Nunatak Ediciones, 2008.

Larrea, Antonio y Jorge Montealegre. Rostros y rastros de un canto. Santiago: Nunatak Ediciones, 1997.

Manns, Patricio. Violeta Parra. Barcelona: Ediciones Júcar, 1977.

Morales, Leonidas. Violeta Parra: la última canción. Santiago: Cuarto Propio, 2003.

Neruda, Pablo. Obras, tomo I. Buenos Aires: Editorial Losada S.A., 1993.

Parra, Ángel. Violeta se fue a los cielos. Santiago: Catalonia, 2006.

Parra, Isabel. El libro mayor de Violeta Parra. Madrid: Ediciones Michay, 1985.

Parra, Nicanor. La cueca larga. Santiago: Editorial Universitaria, 1958.

Parra, Nicanor. Obra gruesa. Santiago: Editorial Universitaria, 1969.

Parra, Roberto. Las cuecas del tío Roberto. Santiago: Autoediciones Populares / Taller Lican-Rumi, 1989.

—. Vida pasión y muerte de Violeta Parra. Santiago: Ediciones Tácitas, 2017.

Parra, Violeta. Poésie Populaire des Andes. París: François Maspero, 1965.

—. Décimas. Santiago: Ediciones Nueva Universidad / Pomaire, 1970.

—. Cantos folklóricos chilenos. Santiago: Editorial Nascimento, 1979.

—. Obra visual. Santiago: Fundación Violeta Parra / Ocho Libros, 2007.

Pizarro, Gabriela. Cuaderno de terreno: apuntes sobre el romance en Chile. Santiago: Autoediciones Populares / Taller Lican-Rumi, 1987.

Sáez, Fernando. La vida intranquila: Violeta Parra, biografía esencial. Santiago: Editorial Sudamericana, 1999.

Štambuk, Patricia y Patricia Bravo. Violeta Parra: el canto de todos. Santiago: Pehuén, 2011.

Vicuña Cifuentes, Julio. Romances populares y vulgares recogidos de la tradicional oral chilena. Santiago: Imprenta Barcelona, 1912.

www.cancioneros.com EP 